\title{
An overlooked new variety of Tritaxis glabella from India with a note on the consequent new synonyms of Croton lawianus (Euphorbiaceae)
}

\author{
Tapas Chakrabarty ${ }^{1} \&$ Gopal Krishna ${ }^{2}$ \\ ${ }^{14}$, Botanical Garden Lane, Howrah, West Bengal 711 103, India \\ ${ }^{2}$ Central National Herbarium, Botanical Survey of India, Botanic Garden, Howrah 711 103, India \\ *Email: tchakrab@gmail.com
}

\section{ARTICLE HISTORY}

Received: 24 December 2019

Accepted: 19 February 2020

Published: 01 July 2020

\section{KEYWORDS}

Euphorbiaceae; Croton; Tritaxis;

new variety; new synonyms
ABSTRACT

In connection with the taxonomic revision of the family Euphorbiaceae in India, an overlooked new variety,Tritaxis glabella (Thwaites) R.Y. Yu \& Welzen var. praetervisa Chakrab. \& G.Krishna, endemic to India, has been described which was going so far under misapplied names representing Croton lawianus Nimmo. Consequently, three new synonyms have been added to the latter name.

\section{Introduction}

The cosmopolitan family Euphorbiaceae, as per its present circumscription (1), comprises of 214 genera and about 5600 species (2). The family is represented in India by 52 genera and 259 species (as per personal estimate of first author). The Indo-Malesian genus Tritaxis Baill. (previously Dimorphocalyx Thwaites), extending to Australia, comprises 16 species of which 4 species and two varieties are known to occur in India (3). The genus Croton L. comprises 750-1000 species, distributed in the tropics and subtropics of both Old and New Worlds (4). More than two-thirds of the species occur in the New World, of which the majority is South American and West Indian; in India, the genus is represented by 15 species (4).

A revised edition of the publication "The family Euphorbiaceae in India" (5) is currently under preparation by the first author. During this work, it is found that the name Dimorphocalyx lawianus Hook.f. (6) has been widely used in Indian Floras (7-13). Hooker (6) proposed this name for a species of Dimorphocalyx occurring in "Concan" and "Anamallay Hills" which he considered distinct from $D$. glabellus Thwaites of Sri Lanka and Deccan peninsula. Hooker (6) wrote: "I advance this as a species distinct from $D$. glabellus with hesitation; it differs from that plant in the much larger more membranous leaves with longer petioles, the more numerous stamens, the usually much narrower and longer very unequal fruiting sepals, and the fruits and seed which are almost double the size." Eventually Chakrabarty \& Balakrishnan (14), in their regional revision of the genus Dimorphocalyx in India, reduced $D$. lawianus to a variety of $D$. glabellus by pointing out that they differ from each other only in some quantitative overlapping characters, and this view was accepted by Saldanha (15), Govaerts et al. (16) and Balakrishnan \& Chakrabarty (5). However, Chakrabarty \& Balakrishnan (14) overlooked the fact that Hooker's (6) name should be treated as a new combination, i.e. $D$. lawianus (Nimmo) Hook.f. because he cited Trigonostemon lawianus (Nimmo) Müll.Arg. (17) as its synonym which is based on Croton lawianus Nimmo. This way, the said element, i.e. D. lawianus sensu Hook.f. continued to be treated under misapplied names, as a species or a variety. Thus, it is evident that the element recognized by Hooker (6) as Dimorphocalyx lawianus is at present going without a valid name. Hence, the same element is recognized and described herein as a new variety of Tritaxis glabella (Thwaites) R.Y. Yu \& Welzen (3) (previously Dimorphocalyx glabellus).

Croton lawianus Nimmo (18) was originally described on the basis of a collection of Gibson from Bombay at "Bheema Snnker" with very short

(c) Chakrabarty \& Krishna (2020). This is an open-access article distributed under the terms of the Creative Commons Attribution License, which permits unrestricted use, distribution, and reproduction in any medium, provided the original author and source are credited (https://creativecommons.org/licenses/by/4.0/).

To cite this article: Chakrabarty T, Krishna G. An overlooked new variety of Tritaxis glabella from India with a note on the consequent new synonyms of Croton lawianus (Euphorbiaceae). Plant Science Today 2020;7(3):302-307. https://doi.org/10.14719/pst.2020.7.3.715 
description of leaves, fruits and seeds (see Art. 40.1 of ICN [19] concerning valid publications). Although the species was accepted and treated in Indian Floras (see references cited in the taxonomic part), it is so far known from three old collections only including the type (see specimen citation) and it has been declared as a critically endangered endemic species of peninsular India (20). As already mentioned above, the name $C$. lawianus was misinterpreted and inadvertently treated to denote a species or variety of Dimorphocalyx. Our attention on this misinterpretation was drawn by the recent publication by $\mathrm{Yu}$ et al. (3) who also erred by transferring the name $C$. lawianus to a variety of Tritaxis glabella (Thwaites) R.Y. Yu \& Welzen. Hence, in order to clarify this complex situation, we are also providing here detailed nomenclature, synonymy, typification and description of $C$. lawianus in order to ensure its unambiguous use as a distinct species of Croton. It resembles $C$. tiglium L. in its foliage but differs in the entire leaves with abbreviated petioles, subglabrous ovary and the smaller fruits with accrescent calyx.

\section{Materials and Methods}

The present study is based on the analysis of literature and examination of herbarium specimens preserved at BSI, CAL, DD, G, K and MH.

\section{Taxonomy}

Tritaxis glabella (Thwaites) R.Y. Yu \& Welzen in Taxon 68(5): 932. 2019 var. praetervisa Chakrab. \& G.Krishna, var. nov., differs from var. glabella in having relatively larger leaves, greater number of stamens, larger capsules with larger, unequal accrescent fruiting calyx (Table 1). Fig. $1 \& 2$.

Type: INDIA. Tamil Nadu, Coimbatore District, Karianshola, 780 m, 2 July 1976, M. Chandrabose 47251 (holotype CAL0000033597!; isotypes MH!).

Dimorphocalyx lawianus sensu auct. plur., non Croton lawianus Nimmo, 1839: Hook.f., Fl. Brit. India 5: 404. 1887; Woodrow in J. Bombay Nat. Hist. Soc. 12: 371. 1899; Brandis, Indian Trees 581. 1906; T.Cooke, Fl. Bombay 2: 604. 1906; Bourd., For. Trees Travancore 508. 1908; Talbot, For. Fl. Bombay \& Sind 2: 475. 1911; Pax \& K.Hoffm. in Engl., Pflanzenr. IV. 147. iii (Heft. 47): 31. 1911; C.E.C. Fisch. in Rec. Bot. Surv. India 9(1): 164. 1921; Gamble, Fl. Madras 1337. 1925; Londhe in N.P. Singh et al., Fl. Maharashtra 2: 872. 2001.

Dimorphocalyx glabellus Thwaites, Enum. Pl. Zeyl. 278. 1861 var. lawianus sensu auct. plur., non Croton lawianus Nimmo, 1839: Chakrab. \& N.P. Balakr. in Proc. Indian Acad. Sci. (Pl. Sci.) 100(5): 296, f. 4. 1990; C.J. Saldanha, Fl. Karnataka 2: 130. 1996; Govaerts et al., World Checkl. Bibliogr. Euphorb. 2: 572. 2000; N.P. Balakr. \& Chakrab., Fam. Euphorb. India 205. 2007.

Flowering \& fruiting: Jan. - Dec.

Habit: Trees, 3-6 m high.

Habitat: Fairly common in evergreen forests at elevations ranging from $150-1100 \mathrm{~m}$.
Distribution: Peninsular India - endemic.

Specimens examined (Paratypes): INDIA. Karnataka: Uttara Kannada District, without locality, Talbot s.n. (BSI, herb. acc. nos. 8602, 8605); Falls of Gairsoppa, 27 Nov. 1883, Talbot 759 (CAL); North Kanara forest, May 1919, Bell 5963 (CAL). Kerala: Idukki District, Sabarimalai, 26 Sept. 1972, B.D. Sharma 42037 (MH). Travancore, Near Kaldurthi, 23 May 1884, Bourdilon 248 (CAL, MH); Travancore, s.d., Bourdillon 86 (MH); Porappar, 31 July 1913, Rama Rao 1357 (CAL). Quilon District, Achenkoil, 26 May 1979, M. Mohanan 63042 (CAL, MH). Maharashtra: Malabar and Concan, Stocks \& Law s.n. (CAL, G00319771: image!, K000246897: image!, MH). Concan, Law s.n. (K000246898: image!). Bombay, Dalzell s.n. (CAL, herb. acc. nos. 412189, 412201); ibid., Law s.n. (K000246912: image!). Satara District, Koyna, on way to Jungli Gaigad, 11 Feb. 1979, Koccher 158326 (BSI). Pune District, Kate-pani forest, Ambavone (Lonavla), 25 Mar. 1964, Venkata Reddi 96029 (CAL). Tamil Nadu: Coimbatore District, Karianshoa, 1937, Bor 7909 (DD); Anamalai Hills, 1864, Beddome s.n. (MH). Ramanathapuram District, Nagariar Estate to Sathaankoil, 13 June 1979, Srinivasan 63582 (CAL, $\mathrm{MH}$ ); Periakavu to Deviar Estate, Sethur Hills, 21 July 1980, Srinivasan 65985 (CAL, MH).

Croton lawianus Nimmo in J.Graham, Cat. Pl. Bombay 251. 1839; Dalzell \& A.Gibson, Bombay Fl. 232. 1861; Hook.f., Fl. Brit. India 5: 394. 1887; Talbot, For. Fl. Bombay \& Sind 2: 472, 1911, in obs.; T.Cooke, Fl. Bombay 2: 601. 1906, in obs.; Rama Rao, Fl. Pl. Travancore 366. 1914; Gamble, Fl. Madras 1315. 1925; C.J. Saldanha, Fl. Karnataka 2: 128. 1996; Chakrab. \& N.P. Balakr. in Bull. Bot. Surv. India 34: 57, f. 9. 1997. = Trigonostemon lawianus (Nimmo) Müll.Arg. in Linnaea 34: 212. 1865 \& in DC., Prodr. 15(2): 1105. 1866. = Dimorphocalyx lawianus (Nimmo) Hook.f., Fl. Brit. India 5: 404. 1887, syn. nov. = Dimorphocalyx glabellus Thwaites, Enum. Pl. Zeyl. 278. 1861 var. lawianus (Nimmo) Chakrab. \& N.P. Balakr. in Proc. Indian Acad. Sci. (Pl. Sci.) 100(5): 296. 1990, syn. nov. = Tritaxis glabella (Thwaites) R.Y. Yu \& Welzen in Taxon 68(5): 932. 2019 var. lawiana (Nimmo) Yu \& Welzen in Taxon 68(5): 932. 2019, syn. nov.

Type [lectotype, designated by Chakrabarty \& Balakrishnan (4), p. 57]: India, Bombay, Without precise locality ["Bheema Snnker"], Gibson s.n. (CAL0000033599!; isolectotype K000246856: image!). Fig. 3.

Large trees (as per protologue); branchlets slender, terete, glabrous; young shoots ochraceous stellate-tomentellous. Leaves ovate to ovatelanceolate, $4.5-14 \times 2.5-6 \mathrm{~cm}$, rounded at base, entire along margins, caudate-acuminate or occasionally acute at apex, membranous to chartaceous, glabrous, light yellowish-brown when dry, strongly trinerved at base; lateral nerves slender, 2-4 pairs above the basal, faint to prominent above, conspicuous beneath, tertiary nerves obscure to faint, scalariform; glands $2-4$, at the junction of petiole and lamina on the undersurface, sessile; petioles 4-8 $\mathrm{mm}$ long, 1-2 $\mathrm{mm}$ thick, glabrous, channeled above. Inflorescences terminal, androgynous, racemiform, ca $5 \mathrm{~cm}$ long; bracts subflabelliform and 2-6 $\mathrm{mm}$ long in female, 
Table 1. Differences between Tritaxis glabella var. glabella and var. praetervisa

\begin{tabular}{lll}
\hline Characters & var. glabella & var. praetervisa \\
\hline Leaves & $1.5-12(-15) \times 0.5-4(-5) \mathrm{cm}$ & $(4.5-) 6.5-19 \times(2-)) 3-8 \mathrm{~cm}$ \\
\hline Stamens & $10-11$ & $11-16$ \\
\hline Capsules & $0.7-1 \times 1-1.2 \mathrm{~cm}$ & $1.2-1.5 \times 1.5-1.8 \mathrm{~cm}$ \\
\hline Fruiting sepals & $0.5-1.2(-1.6) \times 0.3-1 \mathrm{~cm}$, equal to subequal & $1.2-3.2 \times 0.4-1.8 \mathrm{~cm}$, unequal \\
\hline
\end{tabular}

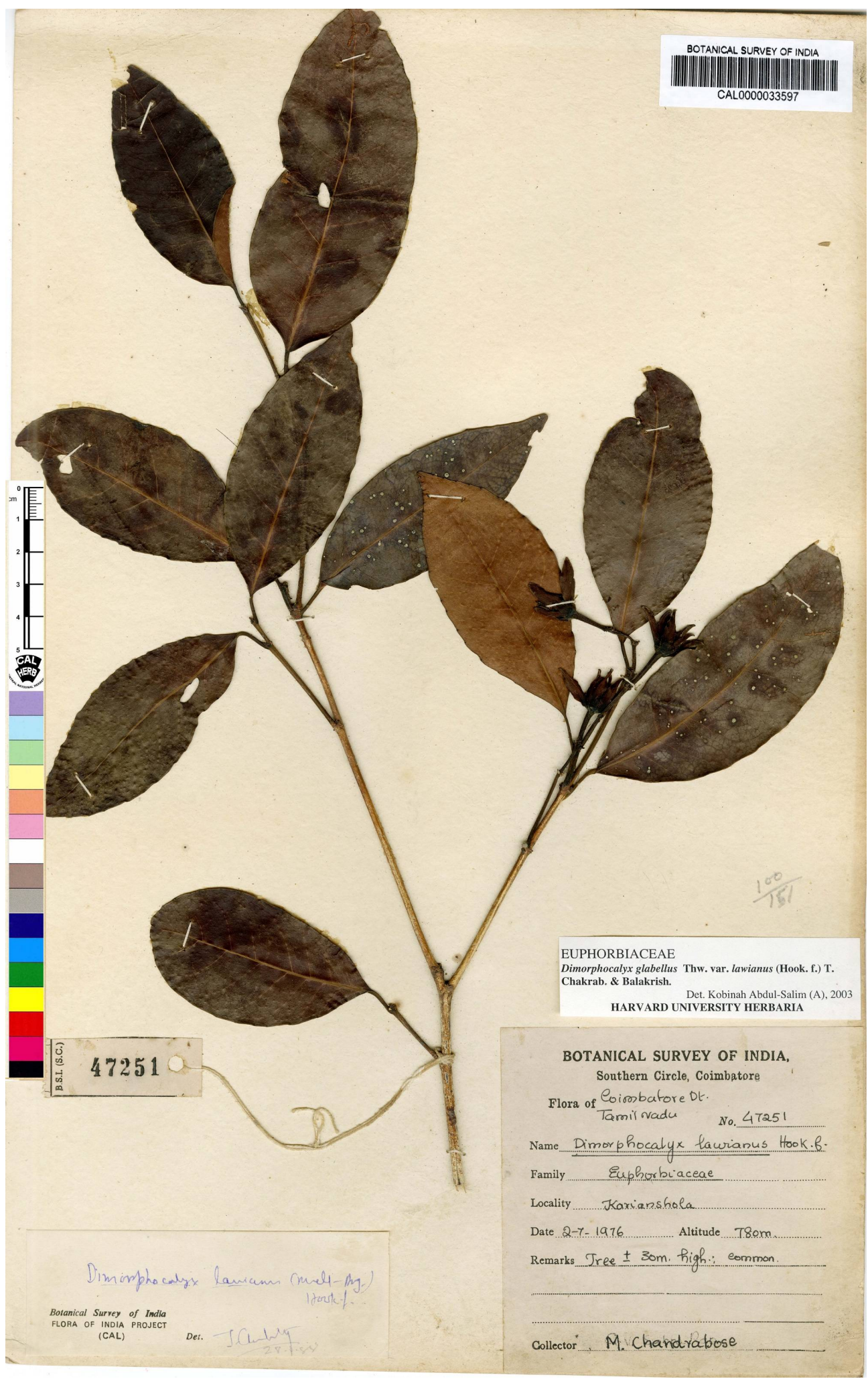

Fig. 1. Holotype of Tritaxis glabella var. praetervisa (๔ Director, Botanical Survey of India, Kolkata).

subulate and $0.8-1 \mathrm{~mm}$ long in male. Male flowers (only immature ones seen): in fascicles at the upper nodes; pedicels short; sepals 5, broadly ovate, elliptic to suboricular, sparsely stellate-pubescent outside; petals 5, oblong; disc glands 5, minute; stamens 15-20, free; anthers oblong. Female flowers: solitary at the 

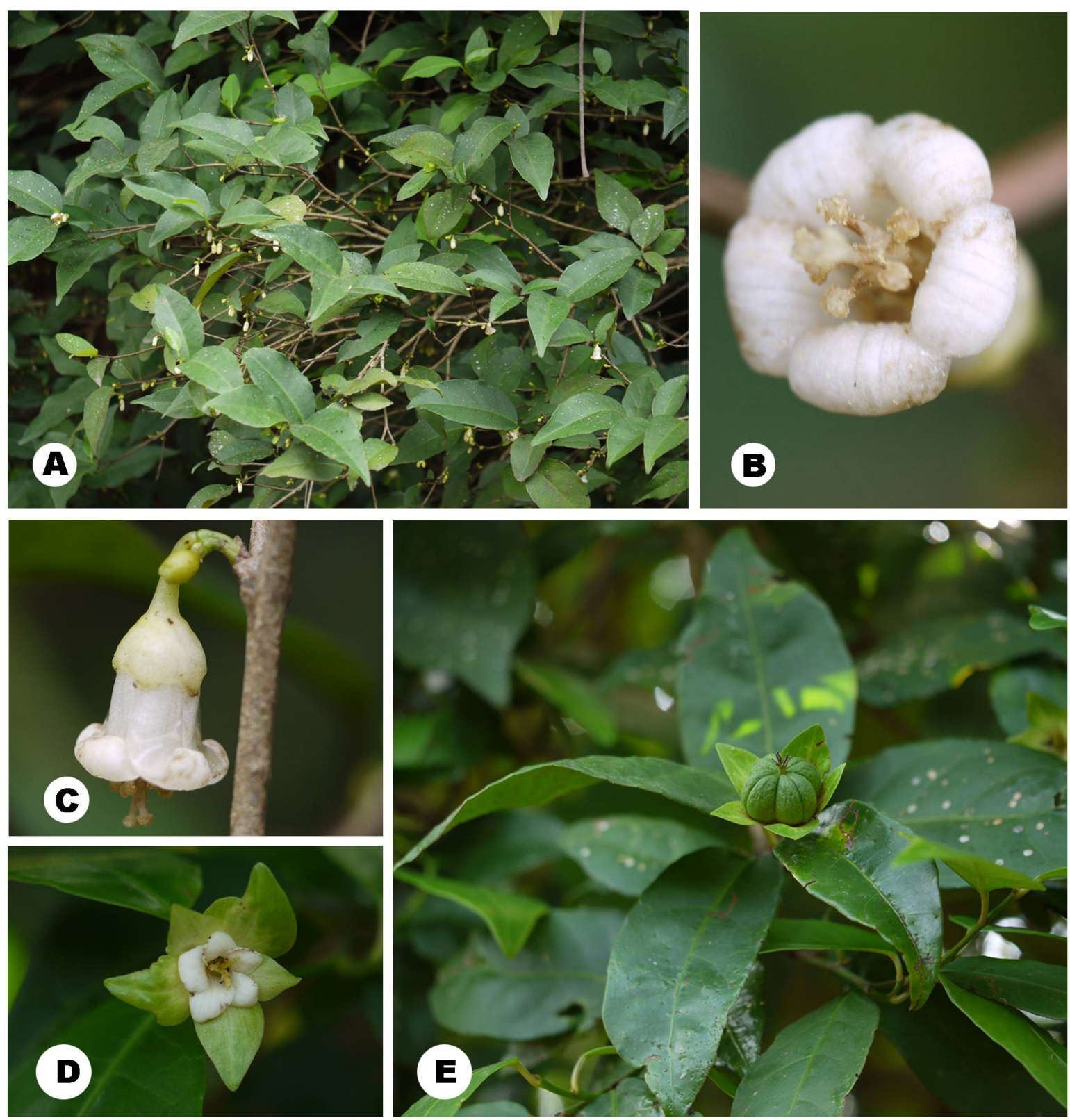

Fig. 2. A-E. Field images of Tritaxis glabella var. praetervisa. A. Habit, B. Male flower (top view), C. Male flower (side view), D. Female flower, E. Fruit.

lower nodes; pedicels 2-2.5 $\mathrm{mm}$ long, sparsely ochraceous stellate-hirsute; sepals 5, elliptic, oblong to ovate, 4-7 × 3-4.5 mm, sparsely ochraceous stellate-hirsute outside, accrescent; petals absent; disc glands 5, in a ring, obcordate, flat; ovary oblong, 2-2.5 mm long, subglabrous; styles 3, 5-6.5 mm long, shortly connate at base into a column (ca $0.5 \mathrm{~mm}$ long), deeply bifid or quadrifid. Fruits capsular, broadly oblong-ellipsoid, 1.3-1.7 × 1.1-1.5 cm, prominently 3-lobed, glabrous, brownish; fruiting pedicels 1-1.5 cm long, 1.2-2 mm thick; fruiting sepals up to $1.8 \times 1.2 \mathrm{~cm}$; seeds broadly oblong, triquetrous, 8-10 × 5-7.5 mm, marbled.

Flowering \& fruiting: Period unknown.

Habitat: Not known; critically endangered.

Distribution: India - endemic.

Specimens examined: INDIA. Bombay, Dalzell s.n. (CAL0000033600, K000246855: image!). Karnataka,
Chikkmagaluru District, Bababudan Hills, Law s.n. (K000246854: image!).

\section{Acknowledgements}

We are thankful to the Director, Botanical Survey of India (BSI), Kolkata and Dr. V.P. Prasad, Scientist - 'E' and Head of Office, Central National Herbarium, BSI, Howrah for providing the necessary facilities, and to Dr. Subir Bandopadhyay, Kolkata for going through the manuscript critically. The field images of Tritaxis glabella var. praetervisa were obtained through the courtesy of Dr. Dinesh Valke.

\section{Competing interests}

The authors declared that they have no competing interest. 


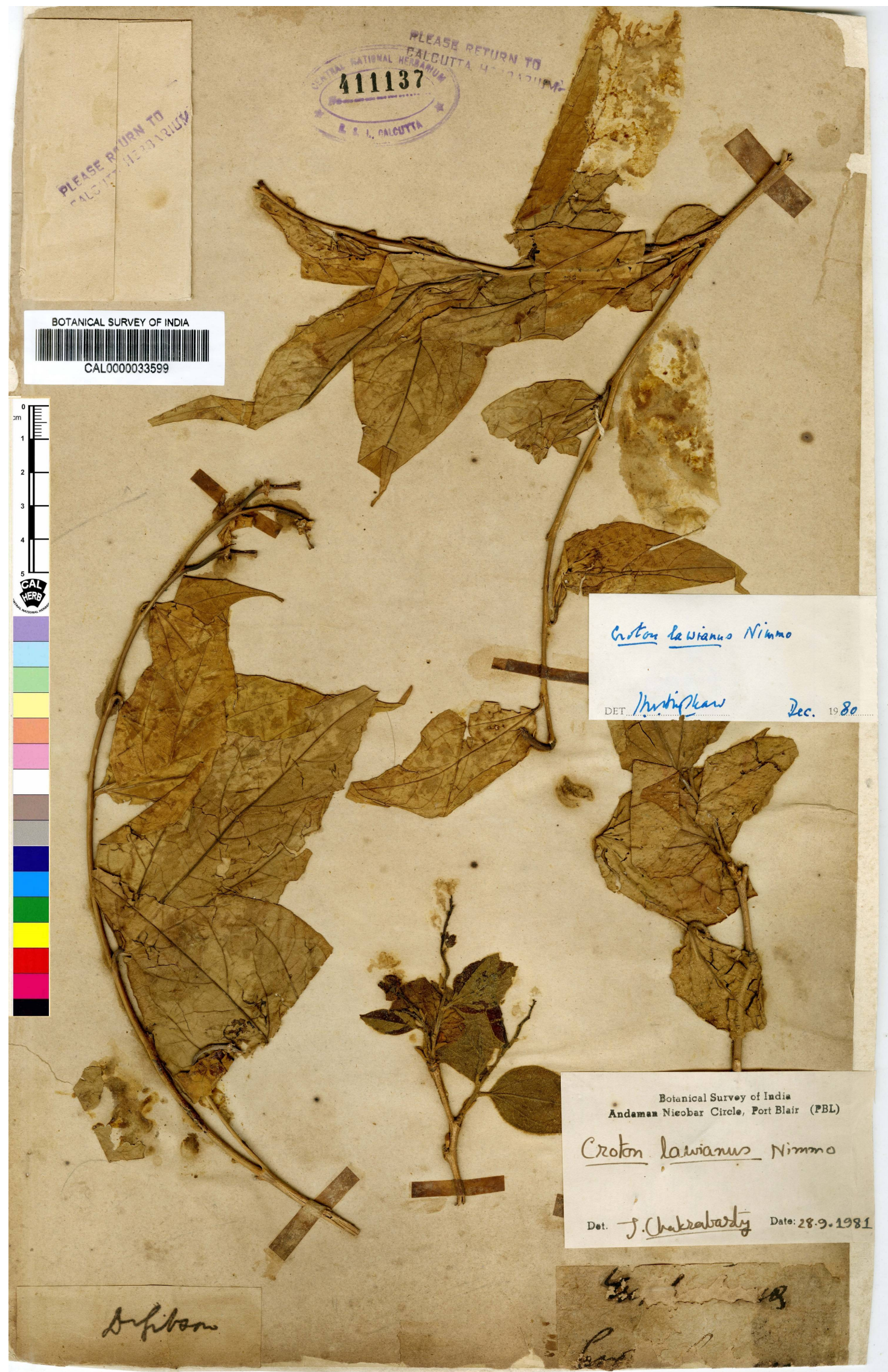

Fig. 3. Lectotype of Croton lawianus (C Director, Botanical Survey of India, Kolkata).

\section{Authors' contributions}

Both authors contributed equally to the work presented in this paper.

\section{References}

1. Angiosperm Phylogeny Group (APG). An update of the Angiosperm Phylogeny Group classification for the orders and families of flowering plants: APG IV. Botanical Journal of the 
Linnean Society 2016;181:1-20. https://doi.org/10.1111/ boj.12385

2. Mabberley DJ. Mabberley’s Plant Book: a portable dictionary of plants, their classification and uses, $4^{\text {th }}$ Ed. Cambridge University Press, UK; 2017. $1120 \mathrm{p}$

3. Yu R-Y, Slik FJW, Welzen PC van. Molecular phylogeny of Trigonostemon and its relatives (Euphorbiaceae). Taxon 2019; 68(5):918-36. https://doi.org/10.1002/tax.12135

4. Chakrabarty T, Balakrishnan NP. A revision of Croton L. (Euphorbiaceae) for Indian subcontinent. Bulletin of Botanical Survey of India 1997;34(1-4):1-88

5. Balakrishnan NP, Chakrabarty T. The family Euphorbiaceae in India, a synopsis of its profile, taxonomy and bibliography. Bishen Singh Mahendra Pal Singh, Dehra Dun; 2007. 500 p

6. Hooker JD. Euphorbiaceae. In: Hooker JD, editor. The flora of British India, Vol. 5 (14). L. Reeve \& Co., London; 1887. pp. $241-$ 462

7. Brandis D. Euphorbiaceae. In: Indian trees. Archibald Constable \& Co., London; 1906. pp. 555-93

8. Cooke T. Euphorbiaceae. In: The flora of the Presidency of Bombay, Vol. 2. Taylor \& Francis, London; 1906. pp. 558-627

9. Bourdillon TF. The forest trees of Travancore. Trivandrum (printed at the Travancore Government Press); 1908. $456 \mathrm{p}$

10. Talbot WA. Forest flora of the Bommay Presidency and Sind, Vol. 2. Poona (Printed by Government at the Photozincographic Department); 1911. $574 \mathrm{p}$

11. Pax F, Hoffmann K. Euphorbiaceae-Cluytieae In: Engler A. (Ed.) Das Pflanzenriech Regni vegetabilis conspectus IV. 147. ii (Heft. 47). Im Auftrage der Preuss. Akademie der Wissenschaften; 1911. pp. 1-124

12. Gamble JS. Flora of the presidency of Madras, Vol. 2, part 7. West Newman \& Co., Adlard \& Son, London; 1925. pp. 11611346
13. Londhe AN. Euphorbiaceae. In: Singh NP, Lakshminarasimhan P, Karthikeyan S, Prasanna, PV (Eds.) Flora of Maharashtra State, Dicotyledons, Vol. 2. Botanical Survey of India, Calcutta; 2001. pp. 852-909

14. Chakrabarty T, Balakrishnan NP. Genus Dimorphocalyx Thw. (Euphorbiaceae) in India. Proceedings of the Indian Academy of Sciences (Plant Sciences) 1990;100(5):285-99

15. Saldanha CJ. Euphorbiaceae. In: Saldanha CJ, editor. Flora of Karnataka, Vol. 2. Oxford \& IBH Publishing Co., New Delhi; 1996. pp. 108-66

16. Govaerts R, Frodin DG, Radcliff-Smith A. World Checklist and bibliography of Euphorbiaceae, Vol. 2. The Royal Botanic Gardens, Kew; 2000. pp. 417-921

17. Müller J. Euphorbiaceae. Vorläufige Mittheilungen aus dem für De Candolle's Prodromus Bestimmten Manuscript über diese Familie. Linnaea; 1865. 34(1): 1-224

18. Nimmo J. Croton lawianus. In: Graham J, editor. A catalogue of the plants growing in Bombay and its vicinity. Government Press, Bombay; 1839. $251 \mathrm{p}$

19. Turland NJ, Wiersema JH, Barrie FR, Greuter W, Hawksworth DL, Herendeen PS, Knapp S, Kusber WH, Li DZ, Marhold K, May TW, McNeill J, Monro AM, Prado J, Price MJ, Smith GF (eds.) International Code of Nomenclature for algae, fungi, and plants (Shenzhen Code), adopted by the Nineteenth International Botanical Congress, Shenzhen, China, July 2017. Koeltz Botanical Books, Glashütten; 2018. https://doi.org/10.12705/ Code.2018

20. World Conservation Monitoring Centre. Croton lawianus. The IUCN Red List of Threatened Species; 1998: e.T38761A10143214. http://dx.doi.org/10.2305/ IUCN.UK.1998.RLTS.T38761A10143214.en 